\title{
Pranggapan dalam Album DAYDREAM Karya Aimer (Kajian Pragmatik)
}

\author{
Lina Rosliana*,Riana Anggun Rianti \\ Progam S1 Bahasa dan Kebudayaan Jepang Fakultas Ilmu Budaya \\ Universitas Diponegoro \\ Jalan Prof. Soedharto SH Tembalang, Semarang 50239, Indonesia \\ *Corresponding Author. Tel 085328716605 \\ Email: linarosliana@lecturer.undip.ac.id
}

\begin{abstract}
Abstrak
Penelitian ini merupakan sebuah kajian pragmatik Bahasa Jepang yang bertujuan untuk mengidentifikasi jenis-jenis praanggapan dalam lagu berbahasa Jepang dengan objek material lagu-lagu oleh Aimer dalam albumnya DAYDREAM dan mendeskripsikan makna praanggapan yang ditemukan dalam lirik lagu tersebut. Data yang digunakan dalam penelitian ini adalah lima lirik lagu Aimer antara lain: FOR LONELY, INSANE DREAM, KATAOMOI , KOWAIRO dan NINELIE. Teori yang digunakan dala m penelitian iniadalah teori pragmatik dan teori praanggapan dari Yule. Metode yang digunakan dalam penelitian ini adalah metode simak dan catat dalam pengumpulan data, lalu dilanjutkan menggunakan metode deskriptif untuk analisis data. Dengan metode deskriptif, akan diidentifikasi penggalan lirik lagu Aimer dalam album DAYDREAM yang mengandung praanggapan lalu menganalisis data dengan pendeskripsian secara mendetail permasala han yang terdapat dalam rumusan masalah penelitian. Tahap penyajian data menggunakan teknik informal. Ha sil penelitian ditemukan bahwa dalam lirik lagu FOR LONELY, INSANE DREAM, KATAOMOI , KOWAIRO dan NINELIE terdapat sejumlah 61 praanggapan, antara lain: praanggapan eksistensial sejumlah 19 data, praanggapan faktif sejumlah 17 data, praanggapan non faktif sejumlah dua data, praanggapan leksikal sejumlah 11 data, praanggapan struktural sejumlah tujuh data dan praanggapan konter faktual sejumlah lima data. Jenis praanggapan yang paling banyak ditemukan adalah jenis praanggapan eksistensial sejumlah 19 data dan praangga pan faktif sejumlah 17 data.
\end{abstract}

Kata Kunci: Aimer; Daydream; pragmatik; praanggapan

\begin{abstract}
The purpose of this study to indentification formpresupposition of Aimer songs in Daydream album and to describe the meaning of presupposition. The resources which used in this research are five song titled For Lonenly, Insane Dream, Kataomoi, Kowairo and Ninelie. This study use theory by Yule.The method of this study is use watch and note method for collection data, then use descriptive method for analysis data. In descriptive method will identify song lyrics by Aimer in album Daydream that contain presupposition and then analysis data with detail descriptive. The data presentation stage use informal method.The result of the study in song lyrics For Lonenly, Insane Dream, Kataomoi, Kowairo dan Ninelie are found that there are 63 data presupposition, such as 19 data of existence presupposition, 19 data of factual presupposition, 2 data of non-factual presupposition, 11 data of lexical presupposition, 7 data of structural presupposition and 5 data of counterfactual presupposition. The form of presupposition that often appears are existence presupposition total of 19 data and factualpresupposition total of 19 data.
\end{abstract}

Keywords: Aimer; Daydream; pragmatics; presupposition

\section{PENDAHULUAN}

Bahasa merupakan alat komunikasi yang digunakan oleh masyarakat dalam kegiatan sehari-hari dan merupakan wadah media untuk menyampaikan suatu makna kepada seseorang baik secara lisan maupun tertulis. Seperti, menyampaikan keinginan, 
ide pikiran dan hasrat. Selain sebagai alat komunikasi, bahasa memiliki ciri yang khas atau unik dan dibangun melalui kebiasaankebiasan dari kegiatan sehari-hari. Menurut Sutedi (2009) satuan bahasa terkecil yang digunakan untuk menyampaikan suatu makna, yaitu kalimat. Kalimat adalah konstruksi gramatikal yang terdiri atas satu atau lebih klausa yang ditata menurut pola tertentu. Sebuah kalimat di dalamnya memiliki dua jenis yaitu kalimat tunggal dan kalimat majemuk. Kalimat tunggal adalah kalimat yang terdiri satu klausa sedangkan kalimat majemuk adalah kalimat yang memiliki lebih dari satu klausa.

Berdasarkan dari definisi bahasa tesebut, terdapat ilmu yang mempelajari atau mengkaji bahasa disebut linguistik. Linguistik terbagi menjadi beberapa jenis salah satunya adalah semantik dan pragmatik. Semantik dan pragmatik merupakan cabang linguistik yang saling berhubungan karena dua cabang tersebut sama-sama mengkaji tentang makna yang membedakannya adalah semantik lebih terfokus pada makna secara aslinya, sedangkan pragmatik mengkaji makna berdasarkan kondisi atau situasi dalam kalimat.

Menurut Tarigan (1986) pragmatik adalah telaah mengenai hubungan antara bahasa dan konteks yang tergramatisikan atau disandikan dalam struktur sesuatu bahasa. Yule (2003) mendefinisikan studi tentang pragmatik lebih banyak berhubungan dengan analisis tentang apa yang dimaksudkan orang dengan tuturantuturannya daripada makna terpisah dari kata atau frasa yang digunakan dalam tuturan itu sendiri. Dapat disimpulkan pragmatik adalah cabang linguistik yang mempelajari tentang maksud penutur. Dalam komunikasi, pragmatik memiliki peran penting karena dapat memahami konteks kalimat dalam bahasa dan memudahkan para penutur dan pendengar saat berkomunikasi. Bidang pragmatik juga mempelajari tentang tindak tutur langsung maupun tidak langsung, presuposisi atau praanggapan, implikatur, deiksis dan sejenisnya. Penelitian ini akan berfokus menjelaskan pada praanggapan. Praanggapan adalah sesuatu yang diasumsikan oleh penutur sebagai kejadian sebelum menghasilkan suatu tuturan (Yule, 2003:43). Dengan kata lain praanggapan sebagai makna yang tersirat atau sebuah asumsi dalam sebuah tuturan. Yule juga membagi macam-macam praanggapan menjadi enam bagian yaitu praanggapan eksistensial, praanggapan faktif, praanggapan leksikal, praanggapan nonfaktif, praanggapan struktural, dan praanggapan konterfaktual.

Dalam penelitian pragmatik terutama praanggapan terdapat beberapa data yang bisa diambil untuk diteliti seperti film atau drama, komik, majalah dan lirik lagu dan lainnya. Jaman sekarang ini, masyarakat selalu mendengarkan lagu setiap waktu, tujuan dari mendengarkan lagu tersebut tergantung dari para pendengar masing-masing, misalnya ada yang untuk menghibur diri atau sebagai pengantar tidur ketika kesulitan untuk tidur. Setiap lagu memiliki makna masing-masing dalam liriknya yang setiap masyarakat dapat mengartikan masing-masing. Lirik lagu tersebut juga dapat dianalisis dalam bidang linguistik terutama dalam bidang pragmatik pada cabang praanggapan.

Penelitian ini berfokus pada jenisjenis praanggapan yang muncul pada lirik lagu Aimer dan menjelaskan makna praanggapan dalam lirik tersebut. Aimer adalah seorang penyanyi solo bergenre pop Jepang yang terkenal dan penulis lirik lagu Jepang dibawah SME Records yang dikelola oleh FOURseam. Nama Aimer berasal dari bahasa Perancis yang berarti "mencintai". Dalam artikel ini akan mengidentifikasi jenis-jenis praanggapan dalam lagu Aimer di album DAYDREAM dan mendeskripsikan makan praanggapan yang ditemukan dalam lirik lagu Aimer di album DAYDREAM. 
Penelitian yang meneliti tentang praanggapan di antaranya skripsi yang berjudul Praanggapan Dalam Lagu - Lagu Jepang (Kajian Pragmatik) yang ditulis oleh Lyana Ellen (Universitas Kristen Maranatha) pada tahun 2008, dan Presupposition In My Chemical Romance's Black Parade Album Lyrics ditulis oleh Adri Lukmana (UIN Sunan Gunung Djati) pada tahun 2019. Pada penelitian yang ditulis olej Lyana, membahas praanggapan yang muncul pada lirik lagu Jepang dan maksim apa saja yang digunakan penulis lirik lagu, sedangkan penelitian yang ditulis oleh Andriberfokus padajenis praanggapan apa yang ditemukan dalam lagu My Chemical romance di album THE BLACK PARADE dan jenis praanggapan apa yag sering dan jarang digunakan di album tersebut. Dari dua penelitian tersebut membahas praanggapan pada objek data lirik lagu bahasa Inggris dan bahasa Jepang, yang membedakannya adalah penelitian ini berfokus pada jenis praanggapan apa yang muncul pada lirik lagu dan mendeskripsikan makna pranggapan yang ditemukan dalam lirik lagu Aimer dalam album DAYDREAM. Penelitian ini menggunakan lagu dari penyanyi Aimer dalam album DAYDREAM.

\section{METODE PENELITIAN}

Metode yang digunakan dalam penelitian ini adalah metode deskriptif. Metode deskriptif merupakan metode penggambaran kenyataan yang ditemukan sebagaimana adanya. Metode deskriptif digunakan untuk mengidentifikasi penggalan lirik lagu Aimer dalam album Daydream yang mengandung praanggapan lalu menganalisis data dengan pendeskripsian secara mendetail permasalahan yang terd apat dalam rumusan masalah penelitian. Pengumpulan data menggunakan metode simak dan catat, yaitu menyimak lagu Aimer lalu membaca liriknya dan mencatat praanggapan yang terdapat pada lirik lagu tersebut. Hasil analisis menggunakan metode informal, yaitu penyajian dengan menggunakan katakata biasa.

\section{HASIL DAN PEMBAHASAN}

\subsection{Praanggapan dalam Album DAYDREAM Karya Aimer}

\subsubsection{Praanggapan dalam Lirik Lagu FOR LONELY}

大好きな人君はどう思う?
Daisuki na hito kimi wa douomou?

'Orang yang kusayangi, apa yang kau pikirkan?’

Penggalan lirik lagu di atas merupakan bait pertama pada lagu Aimer yang berjudul FOR LONELY. Lirik pertama terdapat jenis praanggapan eksistensial. Praanggapan tersebut muncul dengan adanya penggunaan frasa daisuki na hito yang berarti orang yang 'disayangi' atau 'kekasih', menurut Yule (2006) praanggapan eksistensial tidak hanya diasumsikan keberadaannya dalam kalimatkalimat yang menunjukkan kepemilikan, tetapi lebih luas lagi keberadaan atau eksistensi dari pernyataan dalam tuturan tersebut. Frasa tersebut menunjukkan eksistensi atau keberadaan yang menimbulkan praanggapan bahwa penulis lagu dalam lagu tersebut memiliki pasangan. Klausa setelahnya, kimi wa douomou yang berarti 'apa yang kau pikirkan?' memiliki dua jenis praanggapan yaitu praanggapan eksinstensial dan struktural. Kata kimi yang berarti 'kamu' atau 'kau' menunjukkan keberadaan atau eksistensi pasangan penulis lagu dalam lirik lagu tersebut. Sementara itu dou omou yang berarti 'apa yang kau pikirkan' memiliki praanggapan struktural, 
menurut Yule (2006) praanggapan struktural adalah kalimat yang strukturnya sudah diasumsikan kebenarannya, bahwa penutur dapat memakai struktur-struktur yang sedemikian untuk memperlakukan informasi seperti yang diprasangkakan. Sehingga dapat diketahui bahwa lawan bicara sedang memikirkan sesuatu atau ada pikiran yang mengganggunya. Kemudian pada lirik kedua yang berbunyi Sasai na koto de butsukariau bokura wo lirik tersebut dapat diartikan bahwa penulis lagu dan lawan bicaranya merupakan pasangan kekasih dalam lagu tersebut dan mereka sedang bertengkar, hal tersebut dijelaskan pada kata butsukari yang berarti 'bertengkar'.

\subsubsection{Praanggapan dalam Lirik Lagu INSANE DREAM}

また記憶をつきさす焼けた匂い

\section{もう呼吸もできない}

mata kioku wo tsukisasu yaketa nioi

mou kokyuu mo dekinai

'Harum yang terbakar dapat menembus ingatanku lagi'

'Hingga membuatku tak dapat bernafas lagi'

Lirik di atas terdapat jenis praanggapan leksikal, praanggapan tersebut muncul dengan adanya penggunaan kata mou. Menurut Yule (2006) praanggapan leksikal adalah pemakaian suatu bentuk dengan makna yang dinyatakan secara konvensional ditafsirkan dengan presuposisi bahwa suatu makna lain (yang tidak dinyatakan) dipahami. Kata mou dalam kalimat mou kokyuu mo dekinai dan kata mata dalam kalimat mata kioku wo tsukisasu yaketa nioi memiliki arti 'lagi', lalu kata 'lagi' dalam KBBI (Kamus Besar Bahasa Indonesia) memiliki arti kembali seperti semula atau berulang seperti semula. Lirik di atas memiliki arti praanggapan yang berarti bukan pertama kalinya penulis lagu dalam lirik lagu tersebut teringat dengan sesuatu ketika mencium aroma yang terbakar hingga membuatnya dia menjadi kesulitan saat bernafas karena penulis lagu sebelumnya sudah pernah menghirup aroma yang terbakar dan itu membuatnya teringat dengan sesuatu sehingga menjadi kesulitan untuk bernafas.

\subsubsection{Praanggapan dalam Lirik Lagu KATAOMOI}

$$
\text { 「愛してる」 }
$$

\section{Aishiteru}

\section{'Aku mencintaimu'}

Padalirik di atas terdapat jenis praanggapan faktif. praanggapan tersebut muncul dengan adanya penggunaan kata aishiteru yang berarti 'Aku mencintaimu', kata tersebut menunjukkan keaadan penulis lagu yang memiliki perasaan kasih sayang kepada lawan bicaranya dalam hal ini perasaan cinta. Ini dapat dibuktikan dengan melihat konteks dari lirik tersebut. Lirik tersebut menggambarkan situasi atau keadaan tentang seseorang yaitu penulis lagu memiliki perasaan cinta terhadap seseorang yang ada dalam hidupnya, hal ini juga dijelaskan pada lirik-lirik berikutnya. Khususnya pada penggalan lirik Umarekawatta toshitemo deai kata ga saiaku demo mata boku wa kimi ni koisurun da yo yang berarti 'meski kita terlahir kembali dan bertemu dengan cara yang terburuk, aku akan tetap jatuh cinta kepadamu lagi'. Dalam lirik tersebut penulis lagu yang menjelaskan bahwa ia akan tetap memiliki rasa cinta tersebut 
sekalipun mereka terlahir kembali dengan keadaan yang tidak sama seperti sekarang.

\subsubsection{Praanggapan dalam Lirik Lagu KOWAIRO}

私じゃなくて怖いよ

\section{Watashi janakute kowaiyo}

'Aku takut, aku bukanlah diriku sendiri'

Lirik di atas terd apat jenis praanggapan non faktif. Praanggapan tersebut muncul dengan ad anya penggunaan kata kowai yang berarti 'takut' pada akhir kalimat dan diikuti dengan frasa watashi janakute yang berarti 'aku bukanlah diriku sendiri', kata tersebut menunjukkan bahwa penulis lagu berpikir kalau dia bukan dirinya sendiri dan menjadi takut apabila itu terbukti dengan benar. Sehingga penulis lagu menyampaikan bahwa penulis lagu adalah dirinya sendiri. Hal tersebut dibuktikan dalam penggalan lirik yang berbunyi watashi o mi te maboroshi janakute yang berarti 'lihatlah aku, ini bukan ilusi', dalam lirik tersebut penulis lagu menjelaskan ke lawan bicaranya bahwa dirinya bukan ilusi.

\subsubsection{Praanggapan dalam Lirik Lagu NINELIE}

相手をなぞる答えに疲れた

\section{Aite wo nazoru kotae ni tsukareta}

'Aku lelah menjawab dengan mengikuti lawan'

Pada lirik di atas terd apat jenis praanggapan leksikal. Praanggapan tersebut muncul dengan adanya penggunaan frasa kotae $n i$ tsukareta yang berarti 'lelah menjawab', kata kerja tsukareta dalam konteks tersebut merupakan suatu kalimat lampau. Sehingga kata kerja tersebut menunjukkan bahwa penulis lagu sebelumnya sudah sering menjawab pertanyaan orang-orang dengan mengikuti kemauan lawan bicaranya dan untuk saat ini penulis lagu sudah lelah untuk menjawabnya lagi.

\subsection{Tabel}

Berdasarkan dari uraian analasis praanggapan pada lagu Aimer yang berjudul FOR LONELY, INSANE DREAM, KATAOMOI , KOWAIRO dan NINELIE, maka telah ditemukan data sebanyak 61 praanggapan. Hasil rekapitulasi dari total data tersebut dapat dilihat di tabel 3.1 di bahwah ini.

\begin{tabular}{cc} 
Jenis Praanggapan & Jumlah data \\
\hline Eksistensial & 19 \\
Faktif & 17 \\
Non faktif & 2 \\
Leksikal & 11 \\
Struktural & 7 \\
Konter faktual & 5 \\
\hline
\end{tabular}

Tabel 1. Hasil Rekapitulasi 1

\section{KESIMPULAN}

Berdasarkan analisis mengenai praangapan pada lagu Aimer dalam album DAYDREAM, maka dapat disimpulkan sebagai berikut:

1. Analisis lagu Aimer dalam album DAYDREAM khususnya lagu yang berjudul FOR LONELY, INSANE DREAM, KATAOMOI , KOWAIRO dan NINELIE telah ditemukan sebanyak 61 praanggapan pada lagu tersebut, antara lain: praanggapan eksistensial sejumlah 19 data, praanggapan faktif sejumlah 17 data, praanggapan non faktif sejumlah dua data, praanggapan leksikal sejumlah 11 data, praanggapan struktural sejumlah 
tujuh data dan praanggapan konter faktual sejumlah lima data. Jenis praanggapan yang paling banyak ditemukan adalah jenis praanggapan eksistensial sejumlah 19 data dan praanggapan faktif sejumlah 18 data. Terdapat jenis praanggapan yang jumlahnya juga banyak yaitu jenis praanggapan leksikal sejumlah 11 data. Dapat disimpulkan bahwa jenis praanggapan eksistensial dan faktif yang mendominasi praanggapan pada lagu yang berjudul FOR LONELY, INSANE DREAM, KATAOMOI , KOWAIRO dan NINELIE, dalam album DAYDREAM karya Aimer.

2. Makna praanggapan yang paling banyak muncul pada lagu Aimer dalam album DAYDREAM adalah makna yang mendeskripsikan tentang eksistensi atau keberadaan dan fakta tentang tokoh dalam lagu tersebut. Penggunaan kata atau frasa yang memiliki arti tentang keberadaan atau mendukung adanya keberadaan dan fakta tentang tokoh, seperti daisuki na hito yang mendeskripsikan tentang keberad aan bahwa tokoh dalam lagu memiliki pasangan, lalu ijippari yang berarti 'keras kepala' mendeskripsikan bahwa tokoh dalam lagu tersebut memiliki karakter yang keras kepala.

\section{DAFTAR PUSTAKA}

Kridalaksana, Harimurti. 1983. Kamus Linguistik. Jakarta: PT Gramedia.

Karim. 2017. Praanggapan Dalam Pamflet Sosialisasi Pelestarian Ligkungan Di Kabupaten Wakatobi: Kajian Pragmatik. Makassar: Thesis Fakultas Ilmu Budaya. Universitas Hasanuddin.

Koizumi, Tamotsu. 1993. Nihongo Kyoushi no Tame no Gengogaku Nyuumon. Tokyo: Taishukan Shoten.

Muhammad. 2019. Metode Penelitian Bahasa. Jogjakarta: Ar-ruzz Media.

Nadar, F.X. 2009. Pragmatik \& Penelitian Pragmatik. Yogyakarta: Graha Ilmu.

Sutedi, Dedi. 2008. Dasar-Dasar Linguistik Jepang. HUMANIORA UTAMA PRESS: Bandung.

Tarigan, Henry Guntur. 1986. Pengajaran Pragmatik. ANGKASA: Bandung.

Yule, George. 2006. Pragmatik. Pustaka Pelajar: Yogyakarta. 